\title{
Evaluation of the Nutritional Quality and Consumer Acceptability of Wheat-Sesame (Triticum aestivum-Sesame indicum) Composite Bread Blends
}

\author{
Iombor $\mathbf{T T}^{\mathbf{1}}$, Onah $\mathbf{M I}^{\mathbf{1}}$ and Girgih $\mathbf{A T}^{2 *}$ \\ ${ }^{1}$ Department of Home Science \& Management and Department of Food Science \& Technology, University of Agriculture, Makurdi, Nigeria. \\ ${ }^{2}$ Department of Food Science and Technology, University of Agriculture, Makurdi, Benue State, Nigeria.
}

Received: June 09, 2016; Accepted: July 25, 2016; Published: August 24, 2016

*Corresponding author: Dr. Abraham T Girgih, Department of Food Science and Technology, University of Agriculture, PMB 2373, Makurdi, Benue State, Nigeria, Telephone: +234(703) 988-6210; E-mail: girgihat@uam.edu.ng; girgihusa@yahoo.com

\begin{abstract}
The aim of this study was to evaluate the nutritional quality and consumer acceptability of composite bread produced from blends of wheat (Triticum aestivum) and sesame (Sesame indicum) Six (6) composite flour blends were formulated according to the following percent ratios and codes: 100:0 (A), , 90:10 (B) , 80:20 (C) , 70:30 (D) , 60:40 (E) and 50:50 (F) to produce composite breads using the straight dough method. The physicochemical and sensory attributes of the composite bread samples were investigated using standard methods and a fifteen member trained panelists on a 5-point Hedonic scale: where $5=$ extremely liked and $1=$ extremely disliked the characteristics of the bread. The results of the study showed that substitution of wheat with sesame flour up to $30 \%$, significantly $(p<0.05)$ improved the physical properties of the bread with an increased loaf volume of $25-56 \%$ and loaf weight of $4.8-10.5 \%$. In addition, the protein, crude fat, fibre, ash and energy contents of the composite breads showed increases while the carbohydrate and moisture contents exhibited decreases in content The mineral elements content of the composite breads increased significantly $(p<0.05)$ with increased sesame flour substitution. Whole wheat bread (control) was most preferred for all the organoleptic attributes evaluated followed by the $90: 10$ composite bread with the 50:50 bread exhibiting the least preference. Therefore sesame seed flour inclusion in bread making has the ability to improve the physicochemical, sensory characteristics and micronutrient content of the composite samples.
\end{abstract}

Keywords: Physicochemical; Sensory Characteristics; Sesame Seed Flour; Wheat Flour; Composite Flour; Composite Bread; Mineral Elements

\section{Introduction}

Wheat the basic ingredient in bread production is imported into Nigeria involving huge expenditure of foreign exchange earnings thus leading to high cost of bread. In order to make bread affordable to low income earners who constitute the largest patronizing population of consumers, there is need to use novel local nutrient sources underutilized and exploited as flour substitutes for bread production. . The proximate composition of sesame seeds indicates that it has significant amounts of proteins that can be used to produce composite flour with improved protein content for bread production [1, 2]. In addition, sesame (Sesame indicum) has been reported to be a good source of calcium, magnesium, iron, phosphorus, zinc, copper, manganese, selenium, molybdenum, vitamin B1 and dietary fibre. Sesame seeds also contain lignans (sesame and sesamolin) with cholesterol lowering effect, ability to prevent high blood pressure, protect the liver from oxidative damage and increase vitamin E supplies in humans

$[3,4]$. In spite of the rich nutritional quality and health promoting potentials of sesame seeds its utilization and exploitation in the food industry in Nigeria to make it readily available is limited. The commonest uses of sesame in Nigeria have been for oil extraction and as a soup thickener, while in India and China-the eastern parts of the world, it has long been considered a health food capable of providing high energy and prevent ageing [5]. Other uses sesame seeds are put to in asia include the production of instant noodles, tofu, pastes, dressings and marinades.

Bread is a staple food in both developing and developed countries and constitutes one of the important sources of macroand micro-nutrients such as carbohydrate, protein, fibre, vitamins and minerals in the diets of several people around the world [6]. The consumption of bread in Nigeria is steadily increasing because of it's convenience and being a ready-to-eat food product normally consumed at breakfast, lunch, and sometimes dinner [7].

Several composite flours have been used to produce bread and other baked products from cultures of the world. Bread have been produced from whole wheat/full fat or defatted cocoa 
powder flour [8], wheat-cowpea flour [9], wheat-soybean flour [10], fababeans, cotton and sesame seed flour [11], wheat, maize and sweet potato flour [7], wheat, acha and cowpea flour blends [9], wheat and plantain flour blends [12], wheat and yellow maize flour [13], wheat and millet flour blends [14], wheat and yeast fermented rice bran flour blends [15], mix cereals and pulses flour blends for the management of diabetes [16], etc. Aside these outlined flour blends, there are several other potential possibilities for the formulation of composite flours to produce different qualities of extended wheat breads. The ultimate objective of producing composite flour blends/formulations are four fold: to reduce the over dependence on wheat flour as the major ingredient in bread production, promote the utilization and increase exploitation of locally available underutilized food crops for the bakery and confectionary industries, to improve the nutritional quality and create variety of baked products in the market and ultimately reduce the cost of the final baked product. The study was therefore, designed to investigate the impact of defatted sesame flour substitution of wheat flour on the physical, nutrient quality and sensory properties of wheatsesame composite breads.

\section{Materials and Methods}

\section{Sources of Materials}

Sesame seeds, wheat flour, yeast, fat, sugar and other ingredients were purchased from North Bank market in Makurdi metropolis, Benue State, Nigeria. The materials were transported to the Dry Milling Laboratory in the Department of Food Science and Technology, University of Agriculture, Makurdi, Benue State and processed into flour.

\section{Preparation of Ingredients}

Defatted sesame seed flour production: Defatted sesame seed flour was produced using a previous method [17]. Briefly, one kilogram of seeds were manually sorted to remove stones, metals and other extraneous materials such as dust and fine plant residues followed by winnowing. Thereafter, the winnowed seeds were washed with clean tap water, drained and sun dried in a single layer on stainless steel trays, placed on elevated platforms for 6 hours. The sesame seeds were toasted using a microwave oven (SAMSUNG MT1088SB, Tianjin, China) at $260^{\circ} \mathrm{C}$ for 3 minutes. The sesame seeds were then dry milled into flour using a hammer mill and the flour defatted three consecutive times with acetone, decanting the supernatant each time and the resulting sesame flour was left to dry overnight in a fumehood. The dry sesame flour was finally sieved through a $0.5 \mathrm{~mm}$ mesh screen and packed into clean plastic containers until needed for further use.

\section{Bread production}

Composite flour blends formulation: The wheat and sesame seeds flours were blended together on percent dry weight basis into five ratios of 90:10, 80:20, 70:30, 60:40 and 50:50with 100:0 whole wheat flour serving as the control. These flour blends were thoroughly mixed with other ingredients to produce the composite breads that were evaluated for the impact of substitution of wheat flour with sesame seeds flour on the physical, nutritional quality and sensory attributes of the breads. The blend formulations in this study were produced based on standard method previously adopted by [12].

Recipe for bread production: The recipe used for the production of the wheat-sesame composite bread samples and the amount of various ingredients used in this study are shown in Table 1 with a slight modification from the method employed earlier by [7]. The control and five types of composite wheatsesame breads were produced: 100:0, 90:10, 80:20, 70:30, 60:40 and 50:50 corresponding to sample codes A, B, C, D, E and F respectively.

\section{Procedure for bread production}

The bread loaves were produced using the straight dough method [10]. Prior to the actual baking of the breads, baking trials were carried out under laboratory conditions to optimize baking conditions. Composite Flours and doughs were weighed using laboratory-scale (CE- 410I, Camry Emperors, China). Doughs and ingredients were thoroughly mixed to optimum consistency in a Kenwood mixer (Model A 907 D, Kenwood Ltd, England) with low speed of $85 \mathrm{rpm}$ for $1 \mathrm{~min}$. Final dough temperature was $30 \pm 2^{\circ} \mathrm{C}$. Composite mixed doughs were then kneaded and left to proof for $45 \mathrm{~min}$. Proofed doughs were scaled into $105 \mathrm{~g}$ portions, manually shaped and put into oiled tin baking pans. Baking was achieved at $230 \pm 2{ }^{\circ} \mathrm{C}$ in an electric oven (Electric oven SL- 9 Infra red Food Oven, Hubert, China) for 45 min or until the golden brown color was formed. The resulting bread samples were allowed to cool at room temperature $\left(30 \pm 2^{\circ} \mathrm{C}\right)$ for $2 \mathrm{~h}$ after which it was weighed and packaged into transparent polyethylene bags until further analysis were carried out.

\section{Determination of proximate composition}

The moisture, crude protein, fats, fibre and ash contents of the composite bread samples were determined according to method of AOAC (2000). The total carbohydrate was determined by difference: Carbohydrate $=100 \%$ _ $(\%$ moisture $+\%$ protein $+\%$ fat $+\%$ ash $+\%$ crude fiber) while Energy content was determined as previously described [18].

\section{Determination of mineral composition of the bread blendss}

The mineral content profile of calcium, iron, copper, manganese, magnesium and zinc inherent in the bread samples was performed according to a method previously described by [19], while sodium and potassium were estimated by flame photometry method [20].

\section{Physical properties determination}

The loaf volume was determined using the seed displacement method described by [21]. Loaf weight was measured using an electronic balance while the Specific volume was estimated by finding the ratio of the loaf volume of the bread to its corresponding loaf weight: Specific volume $=\mathrm{v} / \mathrm{wt}\left(\mathrm{cm}^{3} / \mathrm{g}\right)$ 
Table 1: Proximate composition of wheat-sesame composite bread blend.

\begin{tabular}{|c|c|c|c|c|c|c|c|}
\hline Samples & Moisture (\%) & Protein (\%) & Fat (\%) & Fiber (\%) & Ash (\%) & CHO (\%) & Energy (Kcal) \\
\hline A(100:0) & $8.38 \pm 0.00^{\mathrm{a}}$ & $13.04 \pm 0.00^{\mathrm{d}}$ & $5.21 \pm 0.00^{\mathrm{f}}$ & $1.16 \pm 0.00^{\mathrm{f}}$ & $0.84 \pm 0.00^{\mathrm{f}}$ & $71.35 \pm 0.01^{\mathrm{a}}$ & $128.17 \pm 0.01^{\mathrm{f}}$ \\
\hline B (90:10) & $7.64 \pm 0.00^{\mathrm{b}}$ & $13.57 \pm 0.00^{\mathrm{c}}$ & $11.44 \pm 0.00^{\mathrm{e}}$ & $1.38 \pm 0.00^{\mathrm{d}}$ & $1.92 \pm 0.00^{\mathrm{e}}$ & $64.04 \pm 0.01^{\mathrm{b}}$ & $137.58 \pm 0.41^{\mathrm{e}}$ \\
\hline $\mathbf{C} \mathbf{( 8 0 : 2 0 )}$ & $7.54 \pm 0.00^{\mathrm{b}}$ & $13.73 \pm 0.01^{\mathrm{c}}$ & $16.21 \pm 0.00^{\mathrm{d}}$ & $1.23 \pm 0.01^{\mathrm{e}}$ & $2.24 \pm 0.00^{\mathrm{d}}$ & $59.03 \pm 0.02^{\mathrm{c}}$ & $145.66 \pm 0.02^{\mathrm{d}}$ \\
\hline $\mathbf{D ( 7 0 : 3 0 )}$ & $6.88 \pm 0.00^{\mathrm{c}}$ & $13.75 \pm 0.00^{\mathrm{c}}$ & $16.61 \pm 0.00^{\mathrm{c}}$ & $1.49 \pm 0.00^{\mathrm{c}}$ & $2.25 \pm 0.00^{\mathrm{c}}$ & $59.01 \pm 0.03^{\mathrm{c}}$ & $146.88 \pm 0.03^{\mathrm{c}}$ \\
\hline $\mathbf{E}(\mathbf{6 0 : 4 0 )}$ & $5.86 \pm 0.57^{\mathrm{d}}$ & $15.42 \pm 0.00^{\mathrm{b}}$ & $22.64 \pm 0.00^{\mathrm{b}}$ & $1.79 \pm 0.00^{\mathrm{b}}$ & $3.22 \pm 0.00^{\mathrm{b}}$ & $50.39 \pm 0.02^{\mathrm{e}}$ & $155.68 \pm 0.01^{\mathrm{b}}$ \\
\hline $\mathbf{F} \mathbf{( 5 0 : 5 0 )}$ & $5.86 \pm 0.02^{\mathrm{d}}$ & $16.00 \pm 0.58^{\mathrm{a}}$ & $22.71 \pm 0.01^{\mathrm{a}}$ & $1.87 \pm 0.00^{\mathrm{a}}$ & $3.35 \pm 0.00^{\mathrm{a}}$ & $50.55 \pm 0.01^{\mathrm{d}}$ & $156.44 \pm 0.01^{\mathrm{a}}$ \\
\hline
\end{tabular}

Mean \pm SD duplicate determination. Means with same alphabet in a column are significantly not different.

Table 2: Mineral element profile of wheat-sesame composite bread (mg/100g).

\begin{tabular}{|c|c|c|c|c|c|c|c|}
\hline Sample & $\mathbf{C a}$ & $\mathbf{M g}$ & $\mathbf{P}$ & $\mathbf{Z n}$ & $\mathbf{F e}$ & $\mathbf{K}$ & Na \\
\hline $\mathbf{A ~ ( 1 0 0 : 0 )}$ & $94.33 \pm 1.53^{\mathrm{e}}$ & $105.00 \pm 3.61^{\mathrm{f}}$ & $582.27 \pm 0.00^{\mathrm{f}}$ & $3.81 \pm 0.00^{\mathrm{f}}$ & $2.86 \pm 0.00^{\mathrm{f}}$ & $23.67 \pm 1.53^{\mathrm{c}}$ & $62.67 \pm 2.52^{\mathrm{e}}$ \\
\hline $\mathbf{B}(\mathbf{9 0 : 1 0 )}$ & $136.33 \pm 3.51^{\mathrm{d}}$ & $284.00 \pm 1.00^{\mathrm{e}}$ & $1115.19 \pm 0.00^{\mathrm{e}}$ & $11.41 \pm 0.00^{\mathrm{e}}$ & $3.31 \pm 0.01^{\mathrm{e}}$ & $17.67 \pm 1.53^{\mathrm{d}}$ & $66.33 \pm 2.89^{\mathrm{b}}$ \\
\hline $\mathbf{C} \mathbf{( 8 0 : 2 0 )}$ & $285.33 \pm 1.53^{\mathrm{c}}$ & $419.33 \pm 6.03^{\mathrm{d}}$ & $1236.71 \pm 0.00^{\mathrm{d}}$ & $14.81 \pm 0.01^{\mathrm{d}}$ & $3.43 \pm 0.00^{\mathrm{d}}$ & $25.67 \pm 2.08^{\mathrm{bc}}$ & $65.33 \pm 1.15^{\mathrm{c}}$ \\
\hline $\mathbf{D} \mathbf{( 7 0 : 3 0 )}$ & $287.67 \pm 4.16^{\mathrm{c}}$ & $445.67 \pm 3.51^{\mathrm{c}}$ & $1381.01 \pm 0.00^{\mathrm{c}}$ & $19.25 \pm 0.00^{\mathrm{c}}$ & $4.96 \pm 0.00^{\mathrm{c}}$ & $27.67 \pm 1.53^{\mathrm{b}}$ & $64.33 \pm 3.05^{\mathrm{d}}$ \\
\hline $\mathbf{E}(\mathbf{6 0 : 4 0}$ & $363.67 \pm 2.51^{\mathrm{b}}$ & $555.67 \pm 3.21^{\mathrm{b}}$ & $1459.49 \pm 0.00^{\mathrm{b}}$ & $23.41 \pm 0.01^{\mathrm{b}}$ & $5.61 \pm 0.00^{\mathrm{b}}$ & $32.67 \pm 2.52^{\mathrm{a}}$ & $66.67 \pm 2.08^{\mathrm{b}}$ \\
\hline $\mathbf{F} \mathbf{( 5 0 : 5 0 )}$ & $419.33 \pm 3.06^{\mathrm{a}}$ & $584.00 \pm 3.00^{\mathrm{a}}$ & $1491.14 \pm 0.00^{\mathrm{a}}$ & $27.45 \pm 0.00^{\mathrm{a}}$ & $6.80 \pm 0.00^{\mathrm{a}}$ & $27.33 \pm 2.08^{\mathrm{b}}$ & $69.33 \pm 1.53^{\mathrm{a}}$ \\
\hline
\end{tabular}

Mean \pm SD duplicate determination. Means with same alphabet in a column are significantly not different.

Table 3: Physical properties of wheat-sesame composite bread blends.

\begin{tabular}{|c|c|c|c|}
\hline Samples & Loaf volume $\left.\mathbf{( C m}^{\mathbf{3}} \mathbf{S p e c i f i c ~ l o a f ~ v o l u m e ~} \mathbf{( c m}^{\mathbf{3}} \mathbf{g}\right)$ & Loaf weight $\mathbf{( g )}$ \\
\hline A (100:0) & $479.89 \pm 0.16^{\mathrm{d}}$ & $2.53 \pm 0.01^{\mathrm{e}}$ & $189.89 \pm 0.15^{\mathrm{c}}$ \\
\hline B (90:10) & $599.85 \pm 0.22^{\mathrm{c}}$ & $2.99 \pm 0.01^{\mathrm{d}}$ & $199.99 \pm 0.01^{\mathrm{b}}$ \\
\hline C (80:20) & $749.83 \pm 0.24^{\mathrm{a}}$ & $3.57 \pm 0.01^{\mathrm{a}}$ & $209.99 \pm 0.01^{\mathrm{a}}$ \\
\hline D (70:30) & $649.80 \pm 0.29^{\mathrm{b}}$ & $3.51 \pm 0.01^{\mathrm{b}}$ & $184.89 \pm 0.16^{\mathrm{d}}$ \\
\hline E (60:40) & $599.83 \pm 0.24^{\mathrm{c}}$ & $3.33 \pm 0.01^{\mathrm{c}}$ & $199.90 \pm 0.15^{\mathrm{c}}$ \\
\hline F (50:50) & $449.99 \pm 0.01^{\mathrm{e}}$ & $2.49 \pm 0.01^{\mathrm{f}}$ & $179.99 \pm 0.01^{\mathrm{e}}$ \\
\hline
\end{tabular}

Mean \pm SD duplicate determination. Means with same alphabet in a column are significantly not different.

Table 4: Result of sensory properties of wheat-Sesame composite bread blends.

\begin{tabular}{|c|c|c|c|c|c|}
\hline Samples & Colour & Taste & Texture & Aroma & Acceptability \\
\hline A (100:0) & $4.67 \pm 0.62^{\mathrm{a}}$ & $3.13 \pm 0.99^{\mathrm{a}}$ & $3.87 \pm 0.64^{\mathrm{a}}$ & $3.27 \pm 0.96^{\mathrm{a}}$ & $3.80 \pm 0.86^{\mathrm{a}}$ \\
\hline B (90:10) & $3.93 \pm 0.70^{\mathrm{b}}$ & $3.00 \pm 0.93^{\mathrm{a}}$ & $3.07 \pm 0.80^{\mathrm{b}}$ & $2.53 \pm 0.83^{\mathrm{b}}$ & $2.87 \pm 0.99^{\mathrm{b}}$ \\
\hline C (80:20) & $3.40 \pm 1.06^{\mathrm{bc}}$ & $2.67 \pm 0.90^{\mathrm{ab}}$ & $2.87 \pm 0.83^{\mathrm{b}}$ & $2.00 \pm 0.85^{\mathrm{b}}$ & $2.73 \pm 0.80^{\mathrm{b}}$ \\
\hline D (70:30) & $3.47 \pm 0.99^{\mathrm{bc}}$ & $2.53 \pm 1.19^{\mathrm{ab}}$ & $2.60 \pm 0.91^{\mathrm{b}}$ & $2.40 \pm 0.63^{\mathrm{b}}$ & $2.93 \pm 0.88^{\mathrm{b}}$ \\
\hline E (60:40) & $3.07 \pm 1.03^{\mathrm{c}}$ & $2.07 \pm 0.88^{\mathrm{b}}$ & $2.80 \pm 0.94^{\mathrm{b}}$ & $2.38 \pm 1.05^{\mathrm{b}}$ & $2.27 \pm 0.96^{\mathrm{b}}$ \\
\hline F (50:50) & $3.07 \pm 1.16^{\mathrm{c}}$ & $2.53 \pm 1.13^{\mathrm{ab}}$ & $2.87 \pm 1.06^{\mathrm{b}}$ & $2.47 \pm 0.99^{\mathrm{b}}$ & $2.60 \pm 1.06^{\mathrm{b}}$ \\
\hline
\end{tabular}

Mean \pm SD duplicate determination. Means with same alphabet in some column are significantly not different.

\section{Sensory Evaluation}

The organoleptic characteristics of the bread samples were evaluated by a 15 member trained panelists drawn from Federal University of Agriculture, Makurdi community, comprising both staff and students who were regular bread consumers. The whole wheat and composite breads were evaluated for taste, aroma, texture, crumb color and general acceptability using a 5-point hedonic scale in which 5 = extremely liked and 1 = extremely disliked as previously used [22].

\section{Statistical Analysis}

The data obtained was subjected to Analysis of Variance (ANOVA) and Duncan Multiple range test was used to separate 
means where significant differences existed and data analyses was achieved using SPSS software version 16.0.

\section{Results and Discussion}

\section{Effect of Physical properties on bread sizes}

The physical parameters that are size related such as bread loaf volume, loaf weight and specific loaf volume were determined for both the whole wheat bread (100:0), the control and the composite wheat-sesame bread samples as shown in Table 2. These three composite wheat-sesame bread size-related physical characteristics (Loaf volume, loaf weight and specific volume) increased significantly $(\mathrm{P}<0.05)$ especially for samples B (90:10) and C (80:20) with $10-20 \%$ replacement of wheat with sesame flour. The highest loaf volumes and weights of the composite breads were exhibited by samples A and B with magnitudes of (599.9 and $749.8 \mathrm{~cm}^{3}$ ) and (199.9 and 209.99 g) respectively when compared to the loaf volume $\left(479.9 \mathrm{~cm}^{3}\right)$ and loaf weight (189.9 g) of sample A, the control. Similarly, the specific loaf volumes of samples B $\left(2.99 \mathrm{~cm}^{3} / \mathrm{g}\right)$ and C $(3.57$ $\mathrm{cm}^{3} / \mathrm{g}$ ) were superior to that of the unextended whole wheat bread, control $\left(\mathrm{A}, 2.53 \mathrm{~cm}^{3} / \mathrm{g}\right)$. The results have indicated that substituting whole wheat flour with up to $20 \%$ sesame seed flours would significantly $(\mathrm{P}<0.05)$ improve the loaf volume, loaf weight and specific loaf volume by 25 to $56 \%$; 5 to $11 \%$ and 18 to $29 \%$, respectively. According to [23] higher loaf volume and weight have positive economic impact on bread at the consumer retail end perspective. Therefore, loaf weight reduction during baking is not a welcome economic quality to the bakers and ultimate vendors as well as consumers who often get attracted to bread loaf with higher volume and weight believing that it has more quantity and quality substance for the same price they are offering for a low loaf volume bread. The specific volume, which is the ratio of the loaf volume to its weight is a physical parameter that, has been generally accepted as a more reliable measure of loaf size. Loaf volume is often affected by the quantity and quality of protein inherent in the flour [24] coupled with the proofing time [25]. On the other hand, loaf weight is mainly estimated by the quantity of dough baked and the amount of moisture and carbon dioxide diffused out of the loaf in the course of baking. In this study, higher temperature and moderate baking time influenced an increase in loaf volume and weight while the reverse effect was observed on the loaf physical characteristics: loaf and specific loaf volumes. Because the bread samples in this study were produced under the same conditions, the variation in loaf volume may be mainly due to differences in the rate of gas exudation [23]. The improvement in the loaf volume, loaf weight and specific loaf volume could be attributed to the increase in structure forming proteins in the sesame flour added which could have enhanced the ability of the dough to rise during proofing resulting in an increase the bread volume [7]. It has been observed that beyond $20 \%$ substitution of the whole wheat with sesame flour led to the production of composite breads with declining loaf volume, loaf weight and specific loaf volume values than that of the control (A).

\section{Proximate composition of composite bread blends}

The results of the proximate composition of the whole wheat (control) and wheat-sesame composite breads are shown in Table 3. There was observed a progressive but significant $(p \leq 0.05)$ increase in crude protein, fat, fibre, ash and energy contents while in contrast, a steady significant $(\mathrm{p} \leq 0.05)$ decrease was observed in the moisture and carbohydrate contents of the composite bread samples when compared to whole wheat bread (control) The moisture content of the composite bread loaves decreased significantly $(\mathrm{p}<0.05)$ with sesame flour inclusion which is good quality attribute as this may increase the shelf life of the bread. With decreasing carbohydrate content and increasing protein, fibre and ash contents, the composite wheatsesame breads could be considered food that may impact on health positively, bringing to bear bioactive benefits such as inhibition or modulation of hyperactive enzymes that could promote cardiovascular diseases and diabetes. High fibre in these breads may be beneficial in enhancing gastrointestinal tract health while the presence of significant amounts of the minerals in the composite bread may activate the metabolic system for effective body physiology. The moisture content of wheatsesame composite breads (5.86-7.64\%) was lower than that of whole wheat bread (8.38\%) and indicates their shelf stability at ambient temperature with appropriate packaging and under suitable environmental conditions. The low moisture content in foods could be as result of some of the water being tightly bound to food matrixes thereby making it unavailable to food pathogens proliferative activities and may promote the long shelf life of the composite bread samples [26]. The low moisture content of wheat-sesame composite breads may also be attributed to the high fat content of the sesame seeds $(44.00 \mathrm{~g} / 100 \mathrm{~g})$ [27] and/ or the flour (56.46\%) (Tokusoglu et al., 2003) which may have influenced negatively water retention of the bread samples. The moisture content of wheat-sesame composite breads (5.86 to $7.64 \%)$ was lower than that $(25.65 \%$ to $28.40 \%)$ reported for wheat-African yam bean composite breads and wheat-sorghum composite biscuit (10.24 to $11.24 \%$ ) [28, 29]. Substitution (10\%) of wheat flour with sesame flour in bread production significantly $(p \leq 0.05)$ increased the protein content of the composite bread samples. The protein content of sesame seeds has been reported to be higher than wheat (FAO, 2012). The high protein content of wheat-sesame composite breads could be used in combating inadequate protein intake and its associated disease condition(s) (Protein Energy Malnutrition (PEM) in developing countries of the world where intake of animal protein food sources are grossly inadequate. The incorporation of sesame seeds in bread production would increase its utilization, diversify its food uses and boost income base of farm families involved in its production at the same time increase the Gross Domestic Product (GDP) of the country while diversifying its income sources. The high fat content of wheat-sesame composite breads may be attributed to high fat content $(61.21 \mathrm{~g} / 100 \mathrm{~g})$ of sesame seeds (FAO, 2012). The fat content of a food material impacts on it energy density, taste and aroma, as evident in the energy content and result of the sensory attributes of wheat-sesame composite breads. The high fat content of wheat-sesame composite breads may increase 
intake of healthier unsaturated fats/fatty acids that promote vitality, while increasing productivity and preventing weight gain associated with unhealthy fat intake (saturated fats). The increase in fibre content of wheat-sesame composite breads may be a function of the high fibre content $(11.60 \mathrm{~g} / 100 \mathrm{~g})$ of sesame seeds. The high fibre content of wheat-sesame composite breads could be used in prevention/management of overweight and obesity disease conditions. Dietary fibre binds with excessive saturated fats in the digestive tract during digestion thereby rendering such fats unavailable for absorption and transportation thereby regulating their circulation and storage. The high fibre content could also be used in the preparation of dishes for diabetics in order to prevent spikes in blood sugar levels after intake of a meal. Ash content of a food product is an indication of its total mineral element content. The high ash value of wheat-sesame composite breads gives an indication of their rich mineral elements content, which could be harnessed in mitigating the effects of inadequate micronutrient intakes plaguing population groups in developed and developing nations of the world. Carbohydrate is the primary energy source (glucose) of brain cells in man. The carbohydrate content of a food material indicates its glycemic index (i.e. its impact on blood glucose level upon digestion and absorption). The carbohydrate content of wheat-sesame composite bread showed that minimal amount of glucose may be released into circulation upon digestion; thereby enabling diabetics maintain a stable blood sugar levels during and after food intake.

\section{Mineral element profile of wheat-sesame composite bread blends}

The mineral content of the wheat-sesame breads are presented in Table 2. Substitution (10\%) of wheat flour with sesame flour in wheat-sesame composite bread production significantly $(\mathrm{p} \leq 0.05)$ increased calcium $(94.33$ - 419.33 $\mathrm{mg} / 100 \mathrm{~g}$ ), magnesium (105 - $584 \mathrm{mg} / 100 \mathrm{~g})$, phosphorus (582.27 - 1491.14 mg/100g), zinc (3.81- $27.45 \mathrm{mg} / 100 \mathrm{~g}$ ), iron (2.86 - $6.80 \mathrm{mg} / 100 \mathrm{~g})$, potassium (23.67 - $27.33 \mathrm{mg} / 100 \mathrm{~g})$ and sodium $(62.6769 .33 \mathrm{mg} / 100 \mathrm{~g})$ content of the bread samples. The mineral elements were highest in wheat-sesame composite bread sample F (50:50). Mineral elements are required in humans in trace amounts to maintain good health, excess of it might be toxic. The high content of metal ions in the wheat-sesame composite breads seen in Table 2 is commensurate with the high ash content shown in Table 1. Phosphorus was particularly high in all the wheat-sesame composite breads, which makes them good sources of this important mineral. Phosphorus is of prime importance in the development of skeletal tissues, formation of nucleic acids DNA and RNA, energy storage and transfer (Adenosine triphosphate, creatine phosphate, intracellular second messenger (cyclic adenosine monophosphate, phosphoproteins, structural roles (formation of cell membrane) and acid-base balance of cells (Gropper et al., 2009). The daily requirement of phosphorus is $700 \mathrm{mg}$ /day for both men and women (pregnant and lactating) age 19 years and older (Food and Nutrition Board, 1997). This amount can easily be provided by any of the wheat-sesame composite breads. Magnesium, the second most abundant mineral in the bread samples is involved in glycolysis, TCA cycle, hexose monophosphate shunt, creatine phosphate formation, $\beta$-oxidation, protein and nucleic acid synthesis, DNA and RNA transcription, cardiac and smooth muscle contractibility and insulin action. The recommended dietary allowance for magnesium is $400 \mathrm{mg}$ for men and 310 mg for women age 19 - 30 years, and $420 \mathrm{mg}$ for men and 320 $\mathrm{mg}$ for women age 31 years and older; which can be provided by any of the composite breads (Food and Nutrition Board, 1997). The intake of these composite breads rich in magnesium may be harnessed in the dietary prevention/management of cardiovascular and renal diseases, diabetes mellitus, toxemia of pregnancy and hypertension (Ma et al., 1995). In diabetes, increased urinary magnesium excretion and/ or inadequate magnesium absorption appear to be associated with poor glycemic control (hyperglucosuria). Magnesium deficiency in turn further impairs insulin secretion and function (Sales and Pedrosa, 2006; Song et al., 2004; Paolisso and Barbagallo, 1997). The high phosphorus content of wheat-sesame composite breads may interfere with absorption of magnesium found in the bread samples, as the divalent ions compete for binding sites in intestinal lumen during digestion/absorption. Calcium the third most abundant mineral in the composite breads is needed for bone mineralization, neurotransmitters, hydrolysis of cell membrane phospholipids and activation/deactivation of enzymes through phosphorylation. The high phosphorus content of wheat-sesame composite breads may also inhibit calcium absorption from the composite breads. Intake of wheat-sesame composite breads would go a long way in prevention/management of osteomalacia/ osteoporosis (elderly), tetany and calcium induced hypertension arising from prolonged inadequate dietary calcium intake. The high calcium content of wheat-sesame composite breads may also be used to decrease susceptibility of man to colon cancer, through calcium ability to bind (and increase excretion of) bile acids and free fatty acids, which act as promoters of cancer by inducing colon cell hyperproliferation. Colon cancer has been linked with calcium-deficient diets in some studies (Barger-Lux and Heaney, 1994; Kleibeuker et al., 1993). An adequate intake of calcium (>800 mg/day) is thought to protect against colon cancer (Food and Nutrition Board, 1997).

The highest $(86.33 \mathrm{mg} / 100 \mathrm{~g}$ ) content of sodium was found in wheat-sesame composite bread sample B (90:10). Within the body sodium plays important roles in the maintenance of fluid balance, nerve transmission/impulse conduction and muscle contraction. Sodium's roles in nerve transmission and muscle contraction involve sodium as part of the $\mathrm{Na}^{+} / \mathrm{K}+$-ATPase pump found in the plasma membrane of cells. The $86.33 \mathrm{mg} / 100 \mathrm{~g}$ sodium content of B (90:10) may provide $5.76 \%$ of the Recommended Daily Intake of the mineral for both men and women age 19 years and older, base on an RDA of $1500 \mathrm{mg} /$ day. The highest (32.67 $\mathrm{mg} / 100 \mathrm{~g}$ ) concentration of potassium was found in composite bread sample E (60:40). Potassium influences the contraction of smooth, skeletal, and cardiac muscles and profoundly affects the excitability of nerve tissue. It is also important in maintaining electrolyte and $\mathrm{pH}$ balance. 


\section{The organoleptic attributes of the composite bread samples}

The results indicated there was preference for whole wheat bread (control) on the basis of colour (4.67), taste (3.13), texture (3.87), aroma (3.27) and overall acceptability (3.80). Among the wheat-sesame composite bread samples however, sample B (90:10) was most preferred for colour (3.93), taste (3.00), texture (3.07) and aroma (2.53) while sample D (70:30) was generally the most preferred bread sample for all the attributes measured. The sensory evaluation of the bread samples showed that the composite breads with higher percentage of sesame flour inclusion were rated lowest for colour, taste, texture and aroma except for overall acceptability that had sample D (70:30) being rated highest. The decrease in crumb colour of the composite bread samples with increasing level of sesame flour substitution could be attributed to their high ash content that impacts dark colour on the loafs.

\section{Conclusion}

In conclusion therefore, substitution of wheat with sesame flour in bread production improved the macro- and micronutrient content of the composite breads. The composite bread samples had better loaf weight, volume and specific loaf volume than that of the whole $(100 \%)$ wheat bread. Commercial production of wheat-sesame composite flour for bread making and other bakery products should be encouraged while further studies be conducted to determine the digestibility and bioavailability of inherent nutrients from these composite flour blends when used in baking for human consumption

\section{References}

1. Pathak N, Rai AK, Kumari R, Bhat KV. Value addition in sesame: A perspective on bioactive components for enhancing utility and profitability. Pharmacognosy Reviews. 2014;8(13):147-155: doi: 10.4103/0973-7847.134249.

2. Quasem JM, Mazahreh AS, Abu-Alruz K. Development of vegetable based milk from decorticated sesame (Sesamum Indicum). American Journal of Applied Sciences. 2009;6(5);888-896: DOI : 10.3844/ajassp

3. Najeeb U, Mirza MY, Jilani G, Mubashir AK, Zhou WJ. Sesame. In Technological Innovations in Major World Oil Crops. 2011;1:131-145.

4. Makinde FM, Akinoso R. Nutrient composition and effect of processing treatments on anti nutritional factors of Nigerian sesame (Sesamum indicum Linn) cultivars. International Food Research Journal. 2013;20(5):2293-2300.

5. Yoshida H, Tanaka M, Tomiyama Y, Mizushina Y. Antioxidant distributions and triacylglycerol molecular species of sesame seeds (Sesamum indicum). JAOCS, Journal of the American Oil Chemists' Society. 2007;84(2):165-172. doi:10.1007/s11746-006-1020-6.

6. Aider M, Sirois-Gosselin M, Boye JI. Pea, Lentil and Chickpea Protein Application in Bread Making. Journal of Food Research. 2012;1:160173.

7. Bibiana I, Grace N, Julius A. Quality Evaluation of Composite Bread Produced from Wheat, Maize and Orange Fleshed Sweet Potato Flours. American Journal of Food Science and Technology. 2014;2(4):109115.

8. Aremu CY, Agiang MA, Ayatse JOI. Protein profiles and organoleptic properties of bread from wheat flour and full-fat or defatted fermented cocoa bean powder. Plant Foods for Human Nutrition. 1995;48(4):287-295.

9. Olapade AA, Oluwole OB. Bread Making Potential of Composite Flour of Wheat-Acha (Digitaria exilis staph) Enriched with Cowpea (Vigna unguiculata L walp) Flour. Nigerian Food Journal. 2013;31(1):6-12. doi: 10.1016/S0189-7241(15)30050-3.

10. Udofia PG, Udoudo PJ, Eyen NO. Sensory evaluation of wheat-cassavasoybean composite flour (WCS) bread by the mixture experiment design. African Journal of Food Science. 2013;7(10):368-374. DOI: 10.5897/AJFS09.108.

11.Abdel-Aal, ES, Sosulski FW, Youssef MM, Shehata AA. Selected nutritional, physical and sensory characteristics of pan and flat breads prepared from composite flours containing fababean. Plant Foods for Human Nutrition. 1993;44(3):227-239.

12. Shittu TA, Egwunyenga RI, Sanni LO, Abayomi L. Bread from composite plantain-wheat flour: I. effect of plantain fruit maturity and flour mixture on dough rheology and fresh loaf qualities. Journal of Food Processing and Preservation. 2013;38(4):1821-1829. DOI: 10.1111/ jfpp.12153.

13. Olaitan NI, Iombor TT, Ugwu LC. Chemical, lutein and zeaxanthin composition of wheat-yellow maize bread for the prevention of atherosclerosis. Advance Journal of Food Science and Technology. 7:827-831.

14.Aprodu I, Banu I. Rheological, thermo-mechanical, and baking properties of wheat-millet flour blends. Food Science and Technology International. 2015;21(5):342-353: doi: $10.1177 / 1082013214536175$.

15. Chinma CE, Ilowefah M, Shammugasamy B, Mohammed M, Muhammad $\mathrm{K}$. Effect of addition of protein concentrates from natural and yeast fermented rice bran on the rheological and technological properties of wheat bread. International Journal of Food Science and Technology. 2015;50(2):290-297. DOI: 10.1111/ijfs.12619.

16. Islam MM, Kamruzzaman M, Islam MS, Elahi MT, Rahman SS, Paul $\mathrm{DK}$, et al. Impact of bread made from mix cereals and pulses on the glycemic profile in type 2 diabetic patients - A randomized controlled trial. Current Nutrition and Food Science. 2015;11(2):136-144.

17. Chinma CE, Igbabul BD, and Omotayo 00. Quality characteristics of cookies prepared from unripe plantain and defatted sesame flour blends. American Journal of Food Technology. 2012;7:398-408.

18. Marero L, Payumo E, Librando E, Lainez W, Gopez M, and Homma S. Technology of weaning food formulations prepared from germinated cereals and legumes. Journal of Food Science. 1988;53(5):1391-1395. DOI: $10.1111 /$ j.1365-2621.1988.tb09284.x

19. Onwuka G. Food analysis and instrumentation: theory and practice. Naphthalic prints, Surulere, Lagos, Nigeria. 2005; 219-230.

20.William H, Latimer G. Official methods of analysis of AOAC international. USA, AOAC International Suite. 2000;500:481.

21. Gregory I, Okpara M. Food analysis and instrumentation theory and Practice. Published by Naphthali Prints, A division of HG Support Nigeria Ltd. 2005;6:140-148.

22. See E, Abdullah W, Nadiah W, Abdul Aziz NA. Physico-chemical and sensory evaluation of breads supplemented with pumpkin flour. ASEAN Food Journal. 2007;14(2):123-130.

23. Shittu TA, Raji AO, Sanni LO. Bread from composite cassava-wheat flour: I. Effect of baking time and temperature on some physical 
properties of bread loaf. Food Research International. 2007;40(2):280290. doi: doi.org/10.1016/j.foodres.2006.10.012

24. Ragaee S, Abdel-Aal ESM. Pasting properties of starch and protein in selected cereals and quality of their food products. Food Chemistry. 2006;95(1):9-18. doi: doi.org/10.1016/j.foodchem.2004.12.012

25.Zghal M, Scanlon M, Sapirstein H. Cellular structure of bread crumb and its influence on mechanical properties. Journal of Cereal Science. 2002;36(2):167-176. doi:10.1006/jcrs.2001.0445

26. Edema MO, Sanni LO, Sanni AI. Evaluation of maize-soybean flour blends for sour maize bread production in Nigeria. African Journal of Biotechnology. 2005;4(9).
27. Bamigboye AY, Okafor AC, Adepoju OT. Proximate and mineral composition of whole and dehulled Nigerian sesame seed. Afr J Food Sci Technol. 2010;1(3):071-075.

28. Adebowale A, Adegoke M, Sanni S, Adegunwa M, Fetuga G. Functional properties and biscuit making potentials of sorghum-wheat flour composite. American Journal of Food Technology. 2012;7(6):372-379. DOI: $10.3923 /$ ajft.2012.372.379

29. Ade I, Ingbian E, Abu J. Physical, Chemical and Sensory Properties of Baked Products from Blends of Wheat and African Yam Bean (Sphenostylis stenocarpa) Water-Extractable Proteins. Nigerian Food Journal. 2012;30(1):109-115. doi: doi.org/10.1016/S01897241(15)30019-9. 